\title{
ESPORT ITTHON: SZERVEZETEK ÉS FEJLESZTÉSI LEHETÓSÉGEK
}

\section{ESPORT IN HUNGARY: ORGANIZATIONS AND DEVELOPMENT OPPORTUNITIES}

\author{
Szabados György Norbert ${ }^{1}$, Bácsné Bába Éva ${ }^{1}$,Fróna Dániel², Bács Zoltán³, Helmeczi András, \\ Kulcsár Gergely5, Ráthonyi Gergely ${ }^{6}$, Kovács Sándor7 \\ ${ }^{1}$ Sportgazdasági és- menedzsment Intézet, Gazdaságtudományi Kar, Debreceni Egyetem, Magyarország \\ 2 Vidékfejlesztés, Regionális Gazdálkodási és Turizmusmenedzsment Intézet, Gazdaságtudományi Kar, \\ Debreceni Egyetem, Magyarország \\ 3Számviteli és Pénzügyi Intézet, Gazdaságtudományi Kar, Debreceni Egyetem, Magyarország \\ 4Közgazdaságtan és Világgazdaságtan Intézet, Gazdaságtudományi Kar, Debreceni Egyetem, Magyarország \\ 5Ihrig Károly Doktori Iskola, Gazdaságtudományi Kar, Debreceni Egyetem, Magyarország \\ ${ }^{6}$ Alkalmazott Informatika és Logisztika Intézet, Gazdaságtudományi Kar, Debreceni Egyetem, Magyarország \\ 7Statisztika és Módszertani Intézet, Gazdaságtudományi Kar, Debreceni Egyetem, Magyarország
}

\section{Kulcsszavak:}

esport, szervezetek, perspektívák

Keywords:

esport, organizations, prospects

\begin{abstract}
Összefoglalás
Igen izgalmas időszaka van a hazai gaming és esport szférának, mely úgy tünik, hogy kiemelt figyelmet kapott a hazai, koronavírus járvány okozta rendkívüli helyzetben. Amennyire lassan közhelynek számít a Fortnite, DOTA2, CS, Overwatch, LOL stb. játékok (sportágak) helyzetére, versenyzőire, sporteseményeire való hivatkozás és nézettség, úgy kerülte el eddig a szakma figyelmét a tevékenység hazai társadalmi és szervezeti hátterének, valamint ezzel összefüggésben fejlesztési lehetőségeinek vizsgálata. A kutatás módszertana az irodalmazás során alkalmazott másodelemzésen túl empirikus kvalitatív interjús felvételezés, melyet szakmabeli szervezetek, sportemberek körében mértünk fel és kerestük tanulmányunkban arra a kérdésre a választ, hogy vajon milyen is a sport hazai helyzete, miféle nehézségek, kilátások jellemzik az ebben a körben müködő egyéneket és szervezeteket, figyelembe véve a társadalmi vonatkozásokat is. A kutatás eredményei arra utalnak, hogy mind szervezeti mind társadalmi oldalról több változás lenne kívánatos.
\end{abstract}

\section{Abstract}

Eco Currently we witness the exciting period in life of the esports, which seems to have received considerable attention even among this extraordinary season caused by the COVID-19. Although referring to the status of games (way of sports), such as Fortnite, DOTA2, Overwatch, LOL, etc together with its competitions, competitors and its follow up became quite common, the profession so far seems to neglect dealing with the social and organizational background of that, also with the development possibilities. The methodology of this essay is, through secondary analysis made during the discussion of the professional literature, is empirical qualitative interview method, which was carried out among professional organizations, sportsmen, and by doing this we sought to answer the question: What is the current national state of this sport, what difficulties, prospects characterize even individuals and organizations in this sphere, also including social specifications. Results point out that numerous changes should be desirable equally from the organizational and social side..

\footnotetext{
1 Kapcsolattartó szerző. Bácsné Bába Éva +36302287178

E-mail cím: bacsne.baba.eva@econ.unideb.hu
} 


\section{Bevezetés}

Mai napig töretlen a vita arról, hogy az esport vajon ténylegesen sportnak tekinthető-e. Az iparág viszont rendületlenül erősödik, globális szinten és hazánkban is. Az eNET, az Esport1 és az Esportmilla közös kutatásából kiderült, hogy immáron hazánkban 24 milliárd forintra tehető az esport forgalma 2018-ban [1].

Magyarországon a globális világhoz mérten később jelentek meg a különböző számítógépes játékok, azonban mára a világtrendek hatására hazánkban is a nemzeti stratégia egyik kiemelkedő tagja az esport. 2013-ban indult el egy először csupán játosokból álló kezdeményezés, az E-sportmilla (Egymillióan a magyar e-sportért) nevü mozgalom, mely 2017-re egyesületté nőtte ki magát. Továbbá 2017-re tehető a Magyar E-sport Szövetség megalakulása is, mely elkezdete a nemzetközi színtérhez való csatlakozást is. Az Egymillióan a magyar e-sportért Egyesület elnöke, Bíró Balázs György kiemelte, hogy céljuk az esport hivatalos sportágként való elfogadása, a hazai esport szervezeti keretének kialakítása, valamint a hazai társadalom oktatása az esporttal kapcsolatosan [2].

Sok tekintetben is hazánkban a 2017-es év volt sorsfordító. Az addig is erősen alulról szerveződő magyar esportot szerető réteg elért a Kormány szintjére is. Ezt követően megrendezésre került az első magyar E-sport és Sport Konferencia az Egymillióan a Magyar Esportért Egyesület és a Magyar Versenysport Szövetség szervezésében 2017. november 16-án. Itt bejelentésre került, hogy 2018-tól érkezik a Magyar Nemzeti E-sport Bajnokság több játékcímben is, illetve 5 esport (1. ábra) szakosztály is megalakult [3]:

- MTK: Az MTK 2017. szeptember 7-én alapította meg esport szakosztályát. Céljuk sikeresen részt venni hazai és nemzetközi versenyeken egyaránt.

- DVSC: A debreceni sport klub indulásakor egyetlen játékban, a FIFA-ban indított csapatot, mely 16 főből álló kerettel rendelkezett.

- DVTK: A Diósgyőr hazánkban az elsők között alapított e-szakosztályt, céljaik között szerepelt csapatok indítása és versenyeztetése a legnépszerübb játékokban, akár nemzetközi porondon is.

- DEAC: A Debreceni Egyetem atlétikai klubja a tipikus példája az alulról szerveződő esportközösségnek. Munkájukat érdemi költségvetés nélkül kezdték meg, csupán az esportok iránti rajongásból.

- HONVÉD: A kispesti klub Lenovo Legion Honvéd Esport Akadémia néven szállt be az esport iparágába a legnagyobb tőkével. Több esport címben 2018 elején induló profi csapatuk mellé akadémiai jelleggel indítottak esportolási lehetőséget az arra vágyók számára.
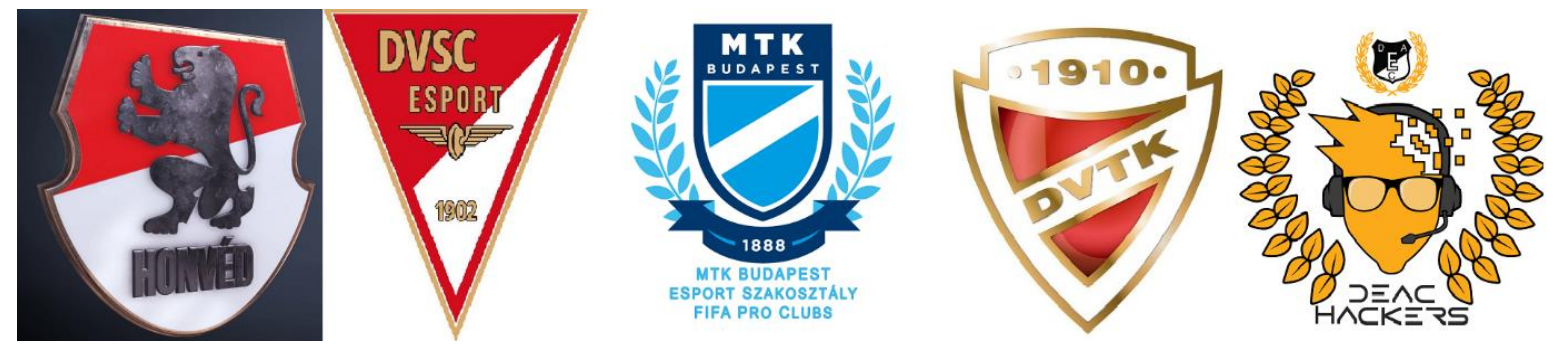

1. ábra: Az első esport szakosztállyal is rendelkező sportegyesületek címerei

Forrás: Internet, 2019.08.14.

A hazai esport további fejlődéséhez, a szépen gyarapodó szakosztályok mellett komolyabb nemzeti stratégiára is szükség van, ennek kapcsán érdemes megvizsgálni a szintér, jelenleg legsikeresebb európai országának Dániának esporthoz való viszonyulását. A Kormány ugyanis felismerte azt, hogy a felnövekvő generáció fogyasztási szokásai hatalmasat változtak, illetve azt, hogy ezen a társadalmi csoportot már máshogy kell elérni, máshogy kell megszólítani. A honatyák bár eleinte kétkedve fogadták a változásokat, de érezhetően meg kívánták ismerni a játékok pozitív hatásait, legyen szó gazdasági, fiziológiai vagy társadalmi faktorokról [4].

Mette Bock kulturális miniszter, egy közelmúltban elhangzott nyilatkozatában többek között arra is kitért, hogy egy megfelelő rendszert kell biztosítani az esportnak, mely gyorsan növekvő és gazdasági szempontból is kiemelkedő helyet foglal el Dániában; a fél Magyarországnyi lakosságú 
ország játékosai a világ legjobbjai között vannak. A fiatalok szokásai és szocializálódásuk sokat változott, ami számos lehetőséget rejt magában. Ezek mellett természetesen aggályok is felmerülhetnek, különösen a szülők szemében; pontosan ezek ismertetését és megbeszélését fogja szolgálni az az esport bizottság, amit még a nyár előtt állít fel a Kormány [5].

A hazai esport gazdasági hatásainak vizsgálata során a joggal merülhet fel a kérdés azzal kapcsolatban, hogy miképp hogyan kerülhetne fel hazánk végérvényesen a világ esport térképére, mint nívós nemzetközi rendezvények, versenyek állandó helyszíne?

Erre kérdésre az „első” érdemi választ a 2018. március 23-25. között Budapesten megrendezett V4 Future Sport Festival adta, melyen a meghívott esport csapatokon kívül Csehország, Lengyelország, Szlovákia és Magyarország legjobb együttesei négy játékban szálltak harcba a dicsőségért, nem utolsó sorban pedig az egymillió euró összdíjazású nyereményekért [6]. A rendezvényt 2019 szeptember 21. és 22. között immár második alkalommal rendezték meg [7].

A további kitörési lehetőségekről két korábbi profi játékos - jelenleg elemzők - a szerb Janko Paunovic és a finn Tomi Kovanen a következőket nyilatkozták [8].

- Paunovic szerint egy lehetséges alternatíva lehet egy ezidáig Magyarországot elkerülő, de a környéken, több helyen is felbukkanó (Kolozsvárott, Kijevben, Bukarestben, Krakkóban, Katowicében) versenysorozatok egyikének (Dreamhack, ESL One, IEM) Budapestre csábítása. Ezek a jellemzően 2-3 napos, pár százezer dollár összdíjazású tornák, melyek ösztönző hatással lennének nemcsak a már komolyan játszó bázisra, de új rajongókat is toborozhatnak egy adott játék profi szegmensének. Ezen túlmenően kiemelte, hogy először ezeket a rendezvényeket is érdemes kicsiben kezdeni: sokkal jobban néz ki egy párezres, de tömött sportcsarnok, mint egy félházas stadion.

- Kovanen szintén jó ötletnek tartja egy már bejáratott sorozat budapesti állomását, ugyanakkor óva int a jelentős mértékű, készpénzben manifesztálódó állami szerepvállalástól; szerinte az csak pazarláshoz vezet.

Meglátása szerint egy nemzeti esportszövetség dolga olyan feladatok ellátása kellene hogy legyen, amiket más nem tud vagy nem akar betölteni, ilyen a gazdasági, politikai és kulturális szereplők részvételre való ösztönzése. Emellett a helyi, profik által már kinőtt, közösségi versenyeket támogatná, mert ezek jelentik a belépőszintet a versenyezni akaró fiataloknak, ugyanakkor hozzátette elsősorban az ilyen eseményekhez nehéz szponzorokat találni, így itt lehetne jó helyet találni az állami pénzeknek.

Következzen néhány gondolat az esport szélesebb körü társadalmi elfogadtatásának egy újabb lehetséges mérföldkövéről: az esport hivatalos sportágként történő elismeréséről. Jelenleg több mint 60 ország van, ahol az esport hivatalosan is elismert sportágnak minősül, ide tartozik többek között Kína, az USA és Dél-Korea is. Franciaországban pedig már az esportolókra is ugyanolyan munkajogi és tartózkodásjogi szabályok vonatkoznak, mint a hagyományos sportot űző profi sportolókra, ellenben továbbra sem ismerik el valódi sportágként. Hazánkban, jogilag nézve az esport jelenleg nem tartozik a hivatalos sportágak [2].

Összegzésképpen elmondhatjuk, hogy az eddig ismertetett negatív sztereotípiák, és az esportban rejlő veszélyek ellenére a jövőben várhatóan a társadalom egyre elfogadóbbá válik a videojátékozás iránt, és pozitív hatásait be tudja építeni és hasznosítani tudja a mindennapokban - legyen szó akár nyelvtanulásról, a finom-motorikus képességek, illetve a koncentráció javításáról, vagy a gamifikáció (játékosítás) egyre erőteljesebb jelenlétéről a munka világában

\section{A vizsgálat anyaga és módszere}

A kutatás lényegi részének célja empirikus jellegű információt kapni az iparági szereplőkkel, érintettekkel. A mérőeszköz tekintetében elsőként összeállítottunk egy hosszabb, 3 blokkra kiterjedő nagyinterjút, több mint 20 kérdéssel. A próbafelvételezés során kiderült, hogy a kérdések egy jelentős része érzékeny terület a megkeresettek számára, más részüket szakmai/üzleti titoknak minősítették, sőt az interjúkra szokásosan jellemző időigény miatt a nagyinterjú mérőeszközét nem lehet jól 
használni. Mindezek miatt, tekintettel az időkorlátokra is dolgoztuk ki a nagyinterjúból kiindulva a felvételezés végső mérőeszközét, mely egy jelentősen rövidített interjú lett, ahol a megkérdezett esporthoz való kapcsolatára és a sportág hazai helyzetére és fejlesztésére vonatkozóan kértünk információt.

A mintavétel logikája tekintetében úgy gondolkodtunk, hogy egyfelől a sportág szereplőinek, érintetteinek alappopulációja egyelőre teljes mértékben nem megismerhető. Másrészt egy ilyen feltáró jellegű kutatás módszertana mindenképp kvalitatív, így feltáró interjúkkal célszerű dolgozni, amelyhez kapcsolódóan a mintavétel sajátossága az, hogy az alapvetően lehet alacsony egyedszámú, és nem kell/nem szükséges/nem szokásos reprezentatívnak vagy véletlen mintavételi alapúnak lennie, ugyanakkor mindenképp szakértői jellegű ismeretekre van szükség (szakértői interjúztatás). $\mathrm{Az}$ interjús felvételezés tekintetében tehát Delphi-módszert alkalmaztunk, melynek lényege elsősorban írásbeli, célzottan szakértői vélemények megismerése. A módszertani irodalmak írnak arról (pl. Barna-Székelyi (2004): Túlélőkészlet az SPSS-hez. Typotex Kiadó, Bp), hogy az írásos megkeresések visszajelzése, válaszadási hajlandósága alapvető́en alacsony, emiatt a mintánkat igyekeztünk egyrészt diverzifikálni, másrészt számban bővíteni. A szakmában történt tájékozódást követően az alábbi alappopulációt állítottuk össze: 1, Játékosok, streamerek/kommentátorok, 2, Klubok, szakosztályok, 3, Esport civil szervezetek (a törvényszéki hiteles adatbázis 12 szervezetet tartalmazott, ebből lett megkeresve), 4, A 3 hazai szövetség képviselői, 5, Hazai programsorozat szervezők.

Az előzetesen jelzettnek megfelelően alacsonyabb válaszadási hajlandósággal szembesültünk, ugyanakkor elmondható, hogy az 5 kategória valamennyiéből sikerült szakértői válaszokat elérni. A kérdésekre adott válaszokat tartalomelemzés módszertanával értékeljük egyrészt kiemelve a tematikus egyezőségeket, valamint grafikus formában megjelenítve a válaszok közötti összefüggéseket.

\section{Eredmények}

A következőkben az esport hazai fejlesztési irányaival, eszközeivel, illetve a kormányzati fejlesztési politika sikere, eredményessége, hatékonysága növelési lehetőségeivel, illetve az erre irányuló javaslatokkal kapcsolatos kérdés kvalitatív elemzésének eredményét mutatjuk be. A vizsgálathoz 10 szakember interjúja állt rendelkezésre, melyet $\mathrm{R}$ statisztikai szoftverrel (R 4.0.0 statisztikai szoftverrel [9] dolgoztunk fel kvalitatív szövegelemző csomagok (tm, wordcloud, igraph) segítségével, illetve hierarchikus klaszterelemzéssel (stats csomag hclust függvény) körkörös dendogramon (dendextend, circlize) külön-külön színnel ábrázolva a klasztereket. Az elemzés első szakaszában megtisztítottuk a szöveget a kötőszavaktól, névmásoktól, névelőktől és minden, az elemzés szempontjából felesleges szótól. Eltüntettük továbbá a számokat, ékezeteket és kisbetúket használtunk, majd kialakítottuk az úgynevezett szövegkorpuszt. A szövegkorpuszból létrehoztuk az úgynevezett kifejezés-szakember mátrixot, amelynek oszlopiban az említett szavak állnak, sorai egyegy szakemberre vonatkoznak, a mátrix értékei pedig az adott említésszámot jelentik. A szófelhőt ebből a mátrixból készítettük a legalább kétszer említett szavakra. A második lépésben a kifejezés dokumentum mátrixból töröltük a ritka kifejezéseket, amelyeket a válaszadódnak kevesebb, mint 20\%-a említett. A további elemzések (szókapcsolati ábra, klaszterezés) alapjául ez a mátrix szolgált.

A korábban kialakított dimenziók közül a legfontosabbnak az állam szerepvállalását és támogatását, illetve az esport fejlesztését a digitális eszközök rendelkezésre állása terén, valamint a társadalmi tudatosság (esport sportként kezelése) növelését az oktatáson keresztül tekinthetjük. Szükséges továbbá a szervezetek törvényi elismerése és a nemzetközi és hazai versenyek, csapatok, játékok szervezése és az eredményesség mérése. Ezzel szorosan összekapcsolódik az utánpótlás nevelése (több gamer), amire szintén nagy figyelmet kell fordítani. 


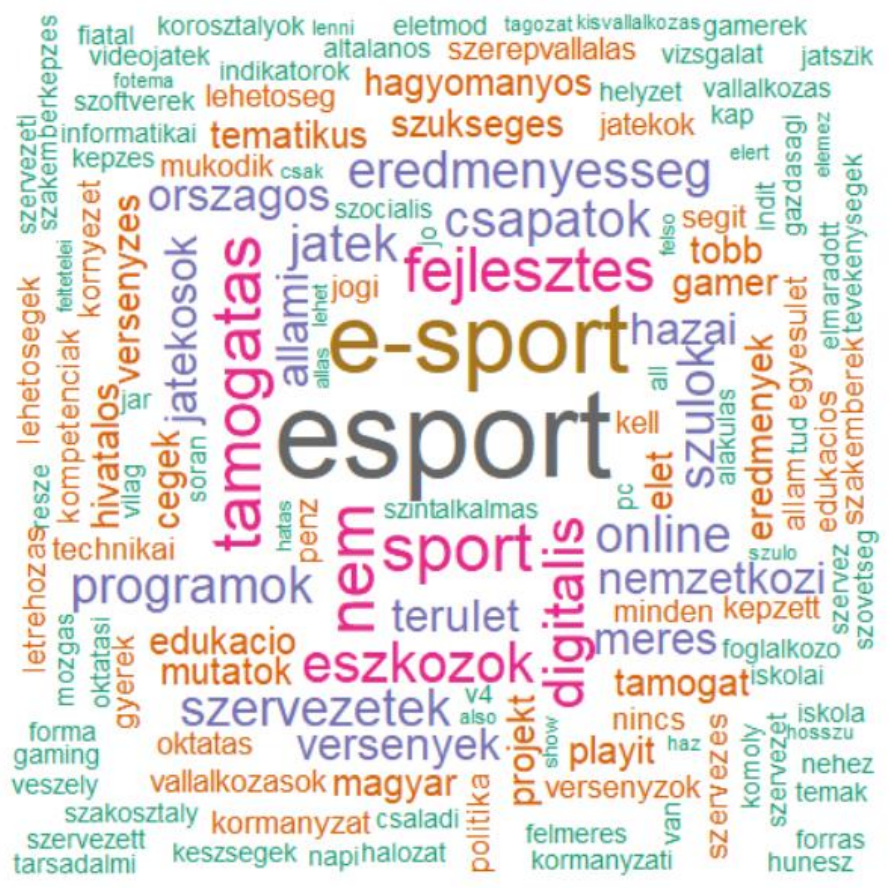

2.ábra: Az esport hazai fejlesztési irányai és lehetőségei szófelhője Forrás: Saját vizsgálatok, 2020.

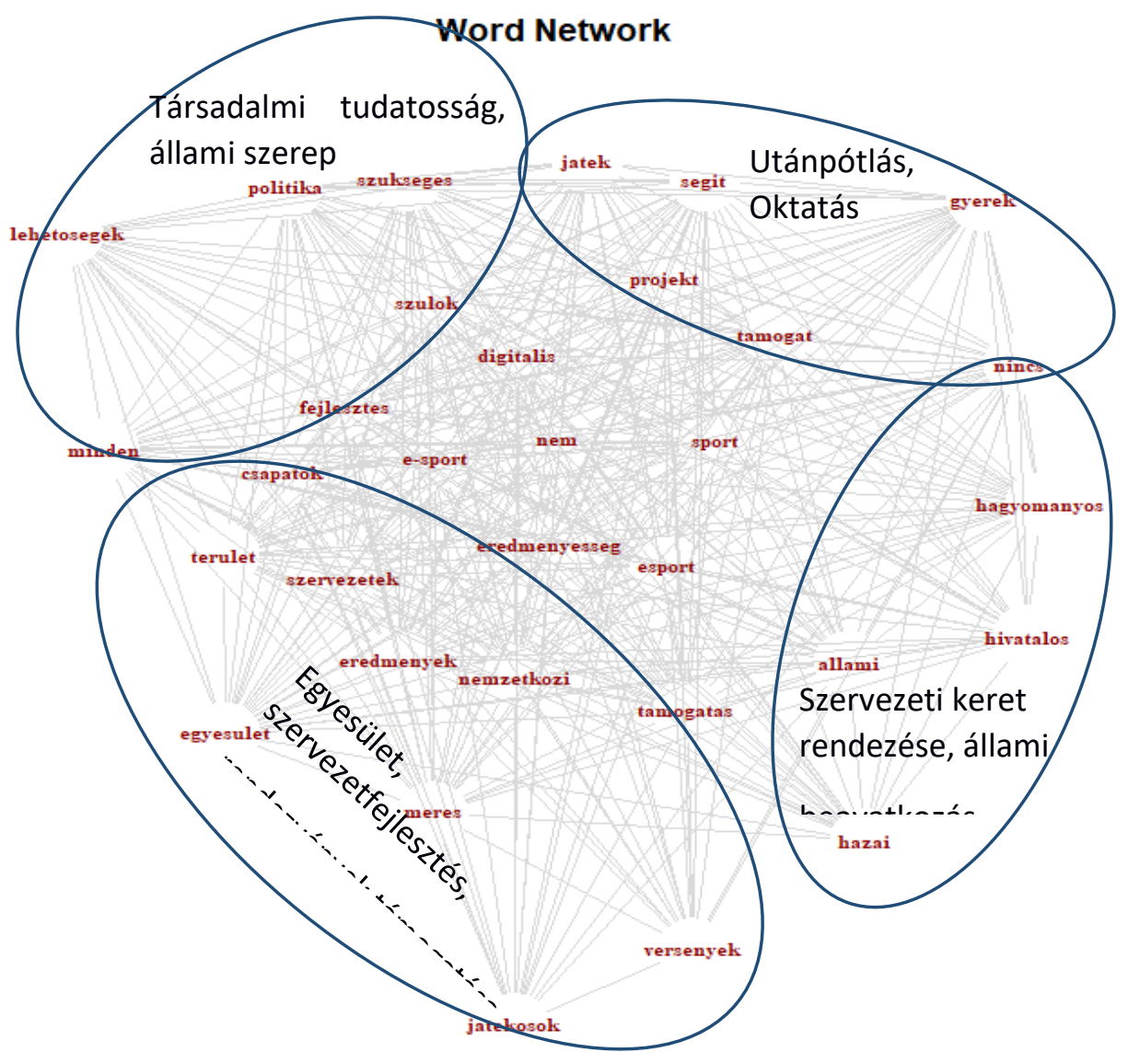

3.ábra: A hazai esportfejlesztés lehetőségeinek szókapcsolati hálózata Forrás: Saját vizsgálatok, 2020. 
A szókapcsolati hálózat (3. ábra) a leggyakrabban előforduló és közösen említett 32 kifejezést tartalmazza, illetve ezek kapcsolatait más kifejezésekkel. Középen láthatjuk azokat a szavakat, amelyek a legtöbb más szóval összefüggésbe hozhatók, ilyenek az esport, sport, támogatás, fejlesztés, eredményesség, digitális kifejezések. A tagadás gyakran fordul elő más kifejezésekkel kapcsolatban, ez arra utal, hogy a szakemberek nem elégedettek a jelenlegi helyzettel. Tulajdonképpen a szókapcsolati ábra is megerősíti a legfontosabb dimenziókat, amelyek mentén lehetőség nyílik az esport támogatására és fejlesztésére. Az ábra alsó részében látjuk az állami beavatkozás egyik fő területét, a szervezeti háttér jogi rendezését, amelyhez szorosan kapcsolódik a szervezetfejlesztés és a rendezvények támogatása. A másik fontos terület az utánpótlás nevelése, amely szorosan összefügg a társadalmi tudatosság növelésével és a politikával, amelynek szerepe van az esport sportként elismertetésével.

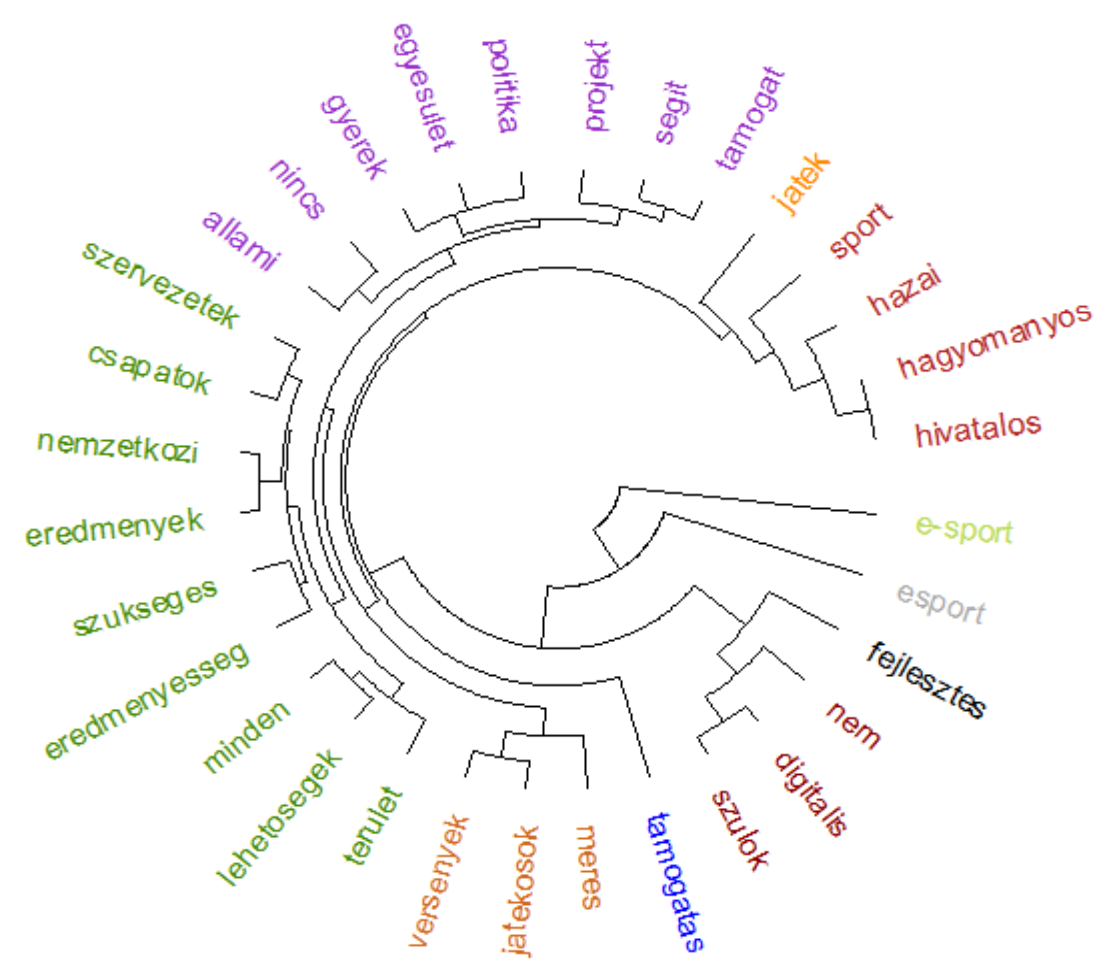

\section{4.ábra: Az esportfejlesztés leggyakoribb kifejezéseinek klaszterezése Forrás: Saját vizsgálatok, 2020.}

Az 4. ábra a kifejezés-szakember mátrixban előforduló szavak alapján készült. Igen értékes információk nyerhetők ki a klaszterekből, amelyeket a korábbi ábrák nem tartalmaztak. Látható, hogy az esporttal kapcsolatban a legközelebb áll a társadalmi tudatosság növelése, azaz a szülők digitális fejlesztése, illetve a digitális oktatás, amely jelenlegi állapotában nem kielégítő. A játék szó külön is kiemelésre került, amelyre különösen figyelmet kell fordítani az oktatás során, mint fontos haszna, eredménye az esportnak. A támogatás szó külön került, mivel ez az összes többi topikhoz kapcsolódik, azaz támogatásra van szükség a rendezvényszervezés, a szervezetfejlesztés és az utánpótlás terén is. Nagyon fontos megállapítás, hogy az állami kifejezés a nincs szóval került egy klaszterbe, ami a segítség és támogatás jelenlegi hiányára utal.

Összefoglalva tehát elmondható, hogy mind a szófelhő ábra, mind a szókapcsolati hálózat és a kifejezések klasztere más-más oldalról mutatja meg az előzetesen saját magunk által feltárt dimenziókat, illetve kiemeli, strukturálja a legfontosabb dimenziókat és azok kapcsolatait. 


\section{Következtetések}

Kutatási érdeklődésünk középpontjában az esport helyzete, társadalmi és szervezeti vonatkozásainak megítélése volt. A kvalitatív kutatás eredményei felmérésünk szerint arra utalnak, hogy mint a többi sportágak esetében sem, itt sem kerülhetőek meg az anyagi vonatkozások, azaz tartós és hathatós állami beavatkozásra lenne szükség, és elsősorban a sportággal foglalkozó szervezetek vonatkozásában. Van még mit fejlődni a további források támogatása terén is. A csekély számú sportszervezetek között már láthatóan kialakult egyfajta hierarchia, ahol a sportág csúcsán állókhoz integrálódva a szervezetek átfogó fejlesztése már el is indulhatna. A sport társadalmi vonatkozásai terén is akad bőven tennivaló, ahol a sportág elfogadottsága még nem igazán magas, és a tudatosítással kapcsolatos tevékenység, illetve az utánpótlási teendők is fontos szerepet kellene kapjanak.

\section{Köszönetnyilvánítás}

A publikáció elkészítését a EFOP-3.6.2-16-2017-0OoO3 számú projekt támogatta. A projekt az Európai Unió támogatásával, az Európai Szociális Alap társfinanszírozásával valósult meg.

\section{Irodalomjegyzék}

[1] Enet. (2019). A magyar videójáték piac több mint felét az e-sport adja Available: https://enet.hu/hirek/a-magyarvideojatek-piac-tobb-mint-felet-az-e-sport-adja/

[2] Pwc (2019). Az e-sport nem játék- Üzleti elemzés Magyarország és a V4-ek e-sport-piacáról. C) 2018 PricewaterhouseCoopers Magyarország Kft.

[3] Szabella O. (2018). Korunk virágzó biznisze? Az e-sport iparág bemutatása. Információs Társadalom. XVIII. évf. 1. sz. pp. 66-92. http://dx.doi.org/10.22503/inftars.XVIII.2018.1.5

[4] ESPORT1.HU (2019b). A Dán Kormány komolyan gondolja az e-sportot - már a nemzeti stratégiát is kidolgozták. https://esport1.hu/news/2019/05/14/esport-dania-esport-strategia-parlament-kormany-miniszterelnok-ben Letöltve: 2019. 08. 14.

[5] ESPORT1.HU (2019a). Dániában új szintre lép az e-sport, ennek örömére a miniszterelnök is beszállt egy meccsre. https://esport1.hu/news/2019/o5/o1/csgo-cs-go-counter-strike-dania-uj-szintre-emeli-orszagaban-az-esportotsziky Letöltve: 2019. 08. 14.

[6] Antalics Á. (2018). Sztárcsapatok, óriási nyeremények - Ez lesz a V4 Future Sport Festival. https://www.origo.hu/sport/laza/20180309-v4-future-sport-festival-esport-videojatek-budapest-bok-csarnok.html Letöltve: 2019. 08. 14.

[7] ORIGO (2019). Újra itt a V4 Future Sports Festival. https://www.origo.hu/techbazis/20190814-v4-future-sportsfestival-2019.html Letöltve: 2019. 08. 14.

[8] Ránki D. (2017). Hogyan legyünk esportnemzet?. https://index.hu/tech/godmode/2017/12/02/hogyan_legyunk_esport_nemzet/ Letöltve: 2019. 08. 14

[9] R Core Team (2020). R: A language and environment for statistical computing. R Foundation for Statistical Computing, Vienna, Austria. 